\title{
A Comparative Analisys of Poverty Theories
}

\section{Un Análisis Comparativo sobre las Teorías de la Pobreza}

DE LA CRUZ-CONTRERAS, Brandon Alan* \& MENDOZA-ALVARADO, Juan José

Universidad Autónoma de Nayarit, Academic Unit of Economics

ID $1^{\text {st }}$ Author: Brandon Alan, De La Cruz-Contreras / ORC ID: 0000-0003-4345-1509, CVU CONACYT ID: 929814

ID $1^{\text {st }}$ Coauthor: Juan José, Mendoza-Alvarado / ORC ID: 0000-0002-1129-6981, CVU CONACYT ID: 72532

\begin{abstract}
Several scholars of the issue of poverty point out that the different ways in which poverty is conceptualized and quantified are of the utmost importance because various poverty measures tend to capture different people as poor. In that sense, this research work seeks to conduct a theoretical and empirical research on theories of poverty, poverty measures and results. Also, we discuss the conceptual framework of the different poverty measures.
\end{abstract}

Poverty, Absolute poverty, Relative poverty, Subjetive poverty, Capabilities approach, Income method, basic needs

\section{Resumen}

Diversos estudiosos del tema de la pobreza señalan que las diferentes formas en que la pobreza se conceptualiza y cuantifica son de suma importancia debido a que diversas medidas de pobreza tienden a capturar a diferentes personas como pobres. En ese sentido, este trabajo de investigación busca realizar una investigación teórica y empírica sobre teorías de la pobreza, medidas de pobreza y resultados. También, discutimos el marco conceptual de las diferentes medidas de pobreza.

Pobreza, Pobreza absoluta, Pobreza relativa, Pobreza subjetiva, Enfoque de capacidades, Método de ingresos, Necesidades básicas

Citation: DE LA CRUZ-CONTRERAS, Brandon Alan \& MENDOZA-ALVARADO, Juan José. A Comparative Analisys of Poverty Theories. Journal-Public Economy. 2019- 3-5: 27-37

\footnotetext{
$\dagger$ Researcher contributing as first author
} 


\section{Introduction}

A notable feature of underdeveloped countries is poverty. The great difficulties of developing economies are related to persistent poverty, the lack of sustainability of growth and development bring with it horrors of poverty: illiteracy, malnutrition, poor health and absolutely ominous perspectives. Poverty is the clearest manifestation of the deprivation of the human being of enjoying the conditions of a dignified life and not only strikes one's existence but also deprives the right to enjoy good health, to have access to education, to have sufficient nutrients. To have a healthy life, you also extinguish your aspirations, hopes and enjoyment and enjoyment of the future.

As such, poverty is not reduced to a monetary problem of income or expenses. Being poor, according to Sen (2001), does not mean living below an imaginary poverty line, for example, an income of $\$ 2$ per day or less, therefore, poverty is multidimensional and does not reduce to the instrumental treatment that manifests in the positive type measures.

The term poverty has different meanings and ways of conceptualizing. Some can be cited. The Royal Academy of Language defines "poor" as needy, who does not have what it takes to live; We note that this definition is reduced to the term "need." Rowntree (1971) defines poverty as the amount of socially acceptable money to meet the minimum needs for the simple maintenance of physical efficiency. For the United Nations Development Program (1997), poverty is the inability of people to live a tolerable life. Authors such as Spicker (1999), identify eleven possible ways of interpreting poverty (need, standard of living, insufficient resources, lack of basic security, lack of ownership, multiple deprivation, exclusion, inequality, class, dependence and unacceptable suffering. fundamental in the

Poverty analysis is the poverty threshold concept, Debraj Ray (1998) defines the poverty threshold as the minimum level of income, consumption or access to goods and services below which individuals are considered to be poor. On the other hand, Atkinson (1981) considers that poverty is substantially related to nutrition.
In that sense, we observe in the literature on poverty the terms of satisfaction of certain needs, the consumption of goods and disposable income, where the definitions are made using absolute, relative and subjective concepts.

This document makes a review of the main theories and approaches on the nature of poverty; describe and compare each theory mentioned in order to discuss the fundamental elements of poverty.

\section{Theory review}

Next, an outline is made of the main ways of conceptualizing and measuring poverty, looking for a differentiating factor in each of the methods that will be mentioned.

Many of the measures presented in this article are frequently used in developing countries, and have been implementing new techniques over time to be able to make closer approximations about who can be considered poor and what are their features. In this part, some of the official poverty measurement measures such as the World Bank, the Economic Commission for Latin America and the National Council for the Evaluation of Social Development Policy in Mexico will also be presented.

\section{The "capabilities" approach}

One of the great contributions to the study of poverty is that proposed by the Nobel Prize in Economics Amartya Sen (1984), the approach of "capabilities" that criticizes the standard of living characterized by the utility experienced by individuals in the face of the consumption of goods, this idea of "capabilities" is based on the fact that the standard of living of an individual is determined by his "capabilities" and not by the assets he possesses, nor by the utility he experiences. Sen exemplifies this idea like this: a bicycle is a good that has different characteristics, including being a means of transport; that characteristic gives the person the ability to transport themselves, and that in turn can provide usefulness to the individual, so that there would be a sequence that begins in the good, passes through the characteristics of the latter, then through the capabilities and, finally, for the utility. 
In addition to this idea, the author points out that the standard of living is also not given by a comparison of people's levels of utility. Understanding utility as a subjective mental reaction to the execution of a capacity and, therefore, the standard of living cannot be objectively assessed, for example, "a complaining rich man may be less happy than a happy farmer, but he has a level of life taller than him. "In short, it would be the power to perform actions that determines the standard of living, and not the objects, their characteristics or their usefulness.

In an analysis by Ravallion (1998), he describes the theory of "capabilities" and its relation to the formulations of "real income" using a theoretical model that links these concepts: It is assumed that household capacities are denoted by the vector c, they are a vector function of the quantities of goods consumed by the household (q), and their characteristics (x), therefore the capacity function is $\mathrm{c}=\mathrm{c}(\mathrm{q}, \mathrm{x})$, in that sense, utility can be considered as a unique value function of the various capacities and $\mathrm{u}=$ w (c) is denoted. The author concludes that by substituting the capacity function with the utility function, the capacities to return to the utility function $\mathrm{u}(\mathrm{q}, \mathrm{x})$ and the corresponding expense function e (p, x, u) can be "resolved." In that sense, the "capacities" are an implicit behavior of demand and the corresponding monetary representations of the utility.

Finally, Sen considers income as an important variable in the study of poverty and states that a person with higher incomes will be able to achieve greater human well-being. This depends on different aspects such as age, gender, social role, location, health, education, justice, etc. He argues that income is related to deprivation, however, it is capacities that determine income.

\section{Absolute and relative poverty}

The difference between "absolute" and "relative" is not found in the definition of poverty, but rather they are ways of interpreting the way they socially shape needs (Spicker, 1999). In that sense, when talking about absolute poverty we refer to a class of measurements that argues that being poor is having less than a definite absolute minimum defined, while relative poverty refers to poverty as having less than others in society, that is.
The needs arise from the comparison with others, and the situation of poverty depends on the general level of poverty.

That said, an outline is made of the absolute and relative approach to poverty.

\section{Absolute Definitions of Poverty}

In this class of measurements we can cite the works of Rowntree (1971) and Orshansky (1965), where they define the absolute minimum in "terms of basic needs", the objective of this method is to specify a set of basic needs (clothing, housing, food, etc.) and in measuring how many people satisfy them. According to Callan and Nollan (1991), people can be poor by clothing, but not poor by food and require direct observation of the consumption patterns of individuals, thus calling it a "direct" approach.

An approach to the "direct" method is the one proposed by Sen (1983) in the income method, which takes as a reference a defined set of basic needs and the minimum level of expenditure necessary to satisfy them. The difference between the direct method and the income method must be emphasized to have an approximation of basic needs. The first directly observes the living conditions of the population, how far from the social standards these living conditions are found will determine the classification of "poor" or "not poor." The second uses income or consumption as an approximation of people's standard of living.

The income level approximation is commonly used in developed countries, for example, in England, where they implement the "primary poverty" measure, in which they specify a diet required to meet the minimum nutritional needs, housing and clothing elements , also an allowance for other expenses. In this method a person is in secondary poverty who live in obvious need but not below the minimum level of expenditure that was obtained when valuing the target basket.

Another approach to the definition and measurement of absolute poverty is that proposed by Watts (1967), Love and Oja (1977), based on Engel's law that argues that the ratio between food and income expenditures decreases when income increases, that is, an absolute minimum is expressed in terms of that reason, below which the person is considered poor.

DE LA CRUZ-CONTRERAS, Brandon Alan \& MENDOZAALVARADO, Juan José. A Comparative Analisys of Poverty Theories. Journal-Public Economy. 2019 
As an example, a ratio of $1 / 3$ would indicate that all households that spend more than one third of their income on food are considered poor. On the other hand, there is the reason total expenditure and income, in which it mentions that a person is in a situation of poverty if their current income is not enough to cover their current expenditure, for example, if they have to resort to loans or spend their savings . According to this category the ratio between total expenditure and total income must be greater than one.

As we have observed, the measurement of poverty is usually carried out through income or consumption and which, in turn, can be expressed in terms of households or individuals, that is, total income and per capita income respectively. According to the first, two households with the same total income have the same level of well-being, although one of them is made up of five people and the other by three. However, it follows that the household needs increase as the number of its members increases, so that an indicator that considers the size of the household will be preferable to the total income; while the per capita income accounts for the size of the household, but dividing its total income by the number of members. In that sense, the object of study becomes the individuals themselves, rather than the homes in which they live.

However, individual needs are not adequately covered by the size of the household because these needs also depend on certain characteristics, such as age, gender, etc. Hence, another dimension to study arises, which is income or consumption adjusted for an "equivalence scale" which shows the relative cost that a household must incur to enjoy the same well-being as a reference household, given its Size and composition

The concept of equivalence scales considers two important elements, the first about the different needs of household members according to their age, gender or other demographic or type of activity characteristics; the second takes into account the existence of "economies of scale", that is, characterized by decreasing marginal costs to achieve the same level of well-being in the presence of a new household member.
On the other hand, the quality of life or the well-being of families can be approximated through the caloric consumption of its members. We observe in the dimensions of extreme poverty, for example, that malnutrition is a fundamental part of the phenomenon, but this is only one aspect of the "standard of living", and not a synonym for poverty. Hence, another method for the identification of poverty, the "anthropometric method" arises. Height according to their age and weight according to height can serve as approximations to nutritional indicators, or as an indicator of health. The main characteristic of this anthropological method is its usefulness in studies on the effects of poverty at the population level.

\section{Definitions of relative and subjective poverty}

As mentioned in the previous section, relative poverty refers to having less than others in society and that is where the concept of relative deprivation is born. We can cite some studies such as Abel-Smith and Townsend (1965), Rainwater (1969), Miller and Roby (1974) who define it with respect to income, and in other Townsend (1979), Desai and Shah (1988) with regarding some goods or events.

According to Sen (1984), the relative method originated in response to the failed poverty studies of the mid-twentieth century, in which the poverty line used was absolute in terms of goods, and did not reflect the new needs of the people over time. Townsend studies this approach, defines the poor as those who lack adequate resources to acquire a certain type of food diet to participate in certain activities and to enjoy a certain level of life and security, focusing on the distribution of the goods of the generated product. In that sense, poverty becomes a relative study in which a person in poverty is considered when he lacks a certain level of income derived from an average income of societies.

Another approach in the definition of poverty is the subjective method, which highlights Hagenaars and Van Praag (1985); Critics of the absolute and relative approach because they mention that in both methods value judgments are required, for example, the fraction of the average or median income where the poverty line is located or in the basket of goods that satisfies caloric consumption. 
The authors point out that the definition of poverty is given by the population and not by who conducts the study. In sum, this method starts from the income levels where respondents are argued about their necessary income levels that they estimate not to be poor, a range is also requested, where sufficient, good and very good income is established to help to well-being.

By way of conclusion we can affirm that the dominant conception of poverty is the traditional methodology of poverty measurement or income insufficiency, however, we have observed that different scholars have proposed different conceptualizations and measurement methodologies, as well as explanatory frameworks on its economic and social nature in order to establish a holistic or multidimensional approach in the way of defining the poor.

The Direct and Unsatisfied Basic Needs Method (NBI)

In previous sections we gave an approximation about the direct method, we mentioned that it uses income or consumption as an approximation to the standard of living of people. This method relates well-being to actual consumption, while the income method relates it to the possibility of making consumption. In this regard Sen (1981) illustrates these arguments: "The ascetic who fasts in his expensive bed of nails will be registered as poor under the direct method; on the other hand, the indirect or income method will classify it differently when considering their level of income, with which a typical person of that community would not have difficulty in satisfying their basic nutritional requirements".

On the method of Unsatisfied Basic Needs. In Latin America, the Unsatisfied Basic Needs method has been characterized as an important contribution in the identification of poverty and certain critical deficiencies of the population, introduced by the Economic Commission for Latin America and the Caribbean (ECLAC) at the beginning of the eighties through censuses, demographics and housing; choosing a series of census indicators that allow to verify whether or not households meet some of their main needs; Once the satisfaction or dissatisfaction of these needs is established, a "poverty map" is constructed, which geographically locates the deficiencies noted.
The basic needs that this approach considers are those that must be satisfied for a household so that their standard of living is considered worthy, according to the standards of the society to which it belongs. It is possible to distinguish between absolute and relative needs. The first are those whose satisfaction is essential for human existence, regardless of the social environment in which the individual develops. The latter have to do with the relative deprivation that members of a given society may experience; An example of this is consumer goods that, on the one hand, are not necessary for survival, but are essential for people to integrate into their social environment.

The needs considered in this method are limited to the following four categories:

1. Access to a home that ensures a minimum standard of home skill

2. Access to basic services that ensure an adequate sanitary level

3. Access to basic education

4. Economic capacity to reach minimum consumption levels

As already mentioned, this method is associated with the elaboration of "poverty maps" at highly disaggregated levels, however, this approach depends on population and housing censuses, where information such as overcrowding, type of housing, lack of health services, absence to primary schools for minors and an indicator of consumption that associates the educational level of the head of the household with the rate of economic dependence.

\section{The integrated poverty measurement method}

Boltvinik (1992) constructed this poverty measurement methodology based on the poverty line (LP) and unsatisfied basic needs (NBI) methods, remember that the LP method consists of comparing income or consumption per capita with the poverty line that is expressed in terms of income; To define the poverty line, the variant of the food normative basket (ANC) was introduced, that to obtain the poverty line it is enough to calculate the cost of the ANC and multiply it by the reciprocal of the Engel coefficient (percentage of expenditure dedicated to food) from some group of households. This procedure is called the CNA variant of the LP method. 
On the other hand, the NBI method consists in comparing the situation of each household in relation to a group of specific needs with a series of norms that express, for each of them, the minimum level below which the need is considered unsatisfied. However, this method has been restricted in Latin American practice due to the limited information available on households in censuses and surveys.

Boltvinik found limitations in both methods, on the one hand the method of LP that consists in satisfying basic needs only depending on income or current private consumption of households, and the NBI method applied in Latin America, choose satisfaction indicators of property needs of consumer assets (housing) or of access rights to government services (water, excreta disposal and primary education), so it does not consider other sources of welfare. Boltvinik points out that both methods turn out to be complementary to each other, insofar as the sources of well-being considered by both methods are different..

In turn, Boltvinik (2010), states in his method that the standard of living of households depends on six sources of welfare, of which two act through the market, current income and nonbasic assets; while the sources of access to free public goods and services, time, knowledge and skills are isolated outside the market.

The author states that during the MMIP the deficiencies associated with the limitations of current income, rights of access to services or government goods of a free nature, property or rights of use, of assets that provide basic consumption services, can be identified. educational levels, skills and abilities, understood as the ability to understand and do, the time available for education, recreation, rest and household chores, the ownership of nonbasic assets and the ability to borrow from home (Boltvinik, 2003, pp. 523).

This method of measuring poverty has been adopted by the capital of Mexico, in addition to the purpose of avoiding duplication of information captured by the income method and that of the NBI, adding the variable time to obtain integrated poverty.

\section{Axioms for poverty measures}

To analyze poverty indices there is an "axiomatic" approach, incorporated by Sen (1976) and subsequently extended or modified by other authors. This approach states that poverty measures must meet a number of conditions, some of which are mentioned below.

The focal axiom points out that, once the poverty line is established, a measure of poverty should not be sensitive to changes in the income of the non-poor. This arises from the idea that changes in the income of people who are above the poverty line do not affect the well-being of poor people. This information can, however, be used to develop other indicators, such as an "indicator of poverty alleviation facility" (Anand, 1977).

The monotonicity axiom states that a measure of poverty must be increased when the income of a poor person decreases. This means that there must be a correspondence between the measure of poverty and the distance of the poor from the line.

According to the transfer axiom, a transfer of money from a poor individual to a less poor individual should increase the measure of poverty. Therefore, this axiom requires that the poverty measure be sensitive to the distribution of income below the poverty line, and in particular, that it assigns a greater weight to the most dispossessed. The weak version of this axiom restricts the analysis to transfers that do not cause an individual to exceed the poverty line.

An extension to this axiom, originally incorporated by Kakwani (1980), is sensitivity to transfers. The aforementioned axiom requires that a transfer of income from a poor person to a less poor person increases the measure of poverty to a greater degree the poorer the person who delivers their resources.

Finally, Foster et al. (1984) have additionally proposed an axiom of monotonicity in subgroups: if poverty increases for a group of people, then total poverty must also increase. This ensures that a change in the income of some individuals affects, in the same direction, the poverty of any group in which these individuals are. 


\section{Count index}

The count is the simplest and best known measure of poverty. Identify the proportion of a population whose income is below the poverty line. It is, not surprisingly, the most commonly calculated measure of poverty. The measure literally counts heads, allowing policy makers and researchers to track the most immediate dimension of the human poverty scale. The count is calculated by comparing the income yi of each household with the poverty line $\mathrm{z}$. (The index $\mathrm{i}=1 \ldots \mathrm{M}$, where $\mathrm{M}$ is the total number of households in the sample.) Specifically, an indicator variable is constructed for each household, taking the value 1 when income falls below the poverty line or 0 if the income is higher:

$\mathrm{I}(y, z)=1$ if $y_{i} \leq z$

$\mathrm{I}(y, z)=0$ if $y_{i}>z$

The counting index is simply the sample average of the variable $I(y, z)$, weighted by the number of people in each household or. The measure is calculated by first counting the number of poor people, G:

$G=\sum_{i=1}^{M} I(y, z) n i$

The total population of the sample can be calculated in a similar way to

$N=\sum_{i=1}^{M} I(y, z) n i$, and the total count is then the reason for the two numbers:

$H=G / N$

Counting is an important descriptive tool. However, as the only guide for allocating resources.

\section{Poverty gap}

A moderately popular measure of poverty is the poverty gap index, which adds the extent to which individuals on average fall below the poverty line, and expresses it as a percentage of the poverty line. More specifically, define the poverty gap $(\mathrm{Gi})$ as the poverty line $(\mathrm{z})$ minus real income (yi) for poor individuals; The gap is considered zero for everyone else. Using the index function, we have

$G i=(z-y i) I(y i<z)$

then the poverty gap index (P1) can be written as
$P 1=\frac{1}{N} \sum_{i=1}^{N} \frac{G i}{Z}$

This measure is the average proportional poverty gap in the population (where the nonpoor have zero poverty gap). Some people find it helpful to think of this measure as the cost of eliminating poverty (in relation to the poverty line), as it shows how much they would have to transfer to the poor to bring their income or expenses to the poverty line (such as a proportion of the poverty line). The minimum cost of eliminating poverty using specific transfers is simply the sum of all the poverty gaps in a population; Each gap is filled to the poverty line. However, this interpretation is only reasonable if transfers can be made perfectly efficiently, for example, with lump sum transfers, which is not plausible. Clearly, this assumes that the legislator has a lot of information; It should not surprise us to discover that a government very "in favor of the poor" would need to spend much more than this on behalf of poverty reduction.

\section{Sen Index}

Another relevant contribution of this author is the so-called "Sen Index" (1976), this poverty measurement methodology contemplates three aspects of poverty, the first considers the percentage of poor for a chosen poverty line or $\mathrm{H}$ index, the magnitude of poverty or index I and income distribution among the poor or Gp index. This index allows quantifying the poor population and detecting when there are income transfers that favor the poorest. This composite index arises from the need to establish the weighted sum of the deficit of poor people and is denoted as follows:

$$
P_{S}=H[I+(1-I) G p]
$$

where $\mathrm{H}$ is the proportion of poor (q) over the total population (n) or incidence of poverty, $\mathrm{H}=\mathrm{q} / \mathrm{n}$. I is the intensity of poverty or gap between the minimum income or poverty line $(\mathrm{z})$ and the income of the poor (yi), I = (z-yi) / z. Gp is the Gini coefficient of income distribution among the poor. This index is an aggregate indicator of inequality and can vary between zero (perfect equality) and one (perfect inequality). 
Then, the Sen index varies, between 0 and 1. In sum, the Ps Index is a function of $H$ (number of poor), I (aggregate poverty gap) and Gp (income distribution inequality, less than poverty line).

\section{Foster, Greer and Thorbecke Index (FGT)}

The FGT index proposed by James Foster, Joel Greer and Erik Thorbecke (1984), is an index of deprivation in private consumption that takes as a reference a certain line of individual poverty, generally obtained this line of poverty from a salary daily minimum of the total population and the economically active population.

The authors point out that certain studies on poverty have demonstrated the usefulness of analyzing a population in subgroups in components and develop a measure of poverty that is additively divisible, in the sense that total poverty is a weighted average of the poverty levels of subgroups This measure is calculated as follows:

$$
F G T=\propto_{(y ; z)}=\frac{I}{n} \sum_{i=1}^{q}\left(\frac{z-y_{i}}{z}\right)^{\propto}
$$

where $\mathrm{z}$ represents the poverty line, and $\mathrm{i}$ is the income of the individual, $\mathrm{n}$ is the size of the population and $\mathrm{q}$ is the number of poor households (for which yi $\leq z$ ). In this index, $\alpha$ is a measure of poverty aversion; that is, at a higher $\alpha$ the FGT $\alpha$ index gives greater weight to individuals who are poorer among the poor. The FGT index is commonly reported as a measure of poverty for $\alpha=0,1$ and 2. When $\alpha=1$, FGT1 calculates the normalized poverty gap, which reflects how far the income of the poor average from the poverty line is. . Thus, FGT1 is sensitive to changes in the income of the poor. Finally, when $\alpha=2$, FGT2 is a measure of the severity of poverty, because individuals whose income is furthest from the poverty line have a higher weighting in the index.

Finally, an advantage of this model is that it can decompose; that is, the contribution to poverty of the population groups classified according to the pre-established characteristics (sex, age, region, occupation, etc.) can be calculated. This property is useful for selecting the groups that have priority in the effort to reduce poverty, as well as for the application of political determinants and strategies.
The way to quantify the poor according to the World Bank

The institutions are key in the analysis of poverty, proof of this is the World Bank, the International Monetary Fund, the United Nations Development Program (UNDP), the InterAmerican Development Bank; They share the same definition and rely on the absolute line of poverty to quantify who are poor and who are not. The World Bank has established the rules of the game and states that the poor are those who are unable to reach a minimum standard of living and another more formal definition of poverty is one that is closely related to hunger, lack of low ceiling which shelter, the situation of illness and not being able to be treated by a doctor, lack of work, poverty is to be afraid of the future and live day by day. Poverty is losing a child due to diseases related to impure water; It is impotence, lack of representation and freedom. (World Bank, 2000).

For the international organization, poverty is variable and different from one country to another and has evolved historically. For this, it has established a general poverty threshold to be able to compare the poverty situation, for example, it has applied figures of $\$$ 1.90 per day at constant 2011 prices. Likewise, the World Bank establishes that the way to measure the poor is through income or consumption levels. An individual is considered poor if their level of income or consumption is below a minimum level that allows them to meet their basic needs. Calling this minimum level "poverty line", which is necessary to meet the basic needs that vary over time and according to the behavior of societies. Therefore, poverty lines change according to time and place, where each nation uses lines that are appropriate in relation to their level of development, norms and social values.

Information on consumption and income is obtained through sampling surveys in which family units are asked about their spending habits and sources of income; complementing these surveys with participatory techniques where they are asked what their basic needs are and how they define the term poverty. 
When estimating poverty worldwide, the reference poverty line of $\$ 1.90$ per day in 2011 dollars is used in terms of the Purchasing Power Parity (PPP), where the PPP measures the purchasing power relative to currencies through countries. The World Bank (2018) has estimated that, in 2015, the number of people living in extreme poverty remained at 736 million people, that is, one person in every 100 in the world.

In conclusion; The World Bank's contributions regarding the definition of poverty consider a very broad spectrum, however for its measurement it is observed that there is a separation between what you want to define and what you want to measure, since it does not incorporate the variables that in your definition proposes to quantify the phenomenon and is only limited to income; from there that a dollar or two is taken as a framework to define the poor or extreme poor.

\section{Discussion and Conclusions}

Each of the different ways of defining and quantifying the poor have different assumptions regarding the definition and measurement of poverty. Some empirical evidence indicates that the poverty measures presented here do not identify the same people as poor.

Comparatively, absolute poverty fundamentally considers the value of the resources necessary to maintain a minimum well-being, which implies the acquisition of a food and non-food basket that allows reaching the minimum levels of satisfaction. Hence, it is necessary to consider a minimum income for a given consumption and, therefore, a certain level of well-being and that when considering a series of basic needs it can be arbitrary since you can never reach an agreement on what are the basic needs . Contrary to the capabilities approach of Sen (1984) who considers income as an important variable in the study of poverty and establishes that a person with higher incomes will be able to achieve greater human wellbeing. This depends on different aspects such as age, gender, social role, location, health, education, justice, etc. However, it is capacities that determine income.

In the analysis of the food / income ratio, we found a problem in this definition because it does not take into account the "economies of scale of different categories of expenditure.
While in the total expenditure / total income many rich people spend more than they perceive as current income, and taking this indicator as a reference, they would be classified as poor.

On the other hand, in the analysis of the equivalence scales we find that the way to build these scales is the estimation of demand functions based on the information contained in the expenditure surveys. However, there is a problem that is that the demand observed does not provide sufficient information to identify levels of well-being or perform

Comparisons between these. Also, the demand depends not only on the needs of each household member, but also on the way in which resources are allocated intrafamiliarly. In that sense, in contrast to nutritional indicators, we affirm that it is not always possible to identify appropriate nutritional requirements.

On the other hand, the quality of life or the well-being of families can be approximated through the caloric consumption of its members. Hence, another method for the identification of poverty, the "anthropometric method" arises. The deficiency of this indicator is that it can omit important deprivations in well-being, although health is correlated with well-being they are not the same thing.

In contrast to the relative approach that people tend to perceive their own well-being in terms of the well-being of others and when considering the condition of poverty based on what others have, this method does not need periodic readjustments at the level of the poverty line, since they automatically occur with a country's income variation. However, the deficiency of this method is that it is directly related to inequality and poverty, although both phenomena are not the same thing; The arbitrariness with which the fraction of income is chosen to obtain the poverty line is also criticized, which is not related to any need or deprivation criteria.

In relation to the subjective poverty that considers the assumption that each individual by himself is the best judge of his own situation, he is not exempt from arbitrariness since, the exact interpretation of the income that people make is unknown, since it can include or not include benefits and other issues. 
There are also problems with the behavior of respondents as they can modify their responses if the poverty line determines the social assistance they receive.

In the axiom stage for poverty measures, the counting index and the poverty gap show a marginal view of the problem, so the implementation of more complete indices is necessary.

The FGT index is favorable in the analysis of poverty profiles and decompositions. However, none of the methods is complete enough to account for the holistic nature of the problem and that many times the indices may overlook important information.

Many authors and even institutions raise the need to integrate different methods to better capture aspects of poverty. For example, the Integrated Poverty Measurement Method, as well as other proposals, in which absolute and relative methods are combined.

Finally, we observe that the dominant conception of poverty is characterized by income or called absolute poverty. In a sense, poverty is not due only to aspects of income or consumption, nor in the possession of goods. To measure poverty, holistic-multidimensional aspects that account for the seriousness of the problem must be considered. For example, time for leisure, access to credit, political and human rights, the freedom to participate in debates and public scrutiny, social and economic institutions such as education and medical care services and among them freedom.

\section{References}

Anand, S. (1977). ASPECTS OF POVERTY IN MALAYSIA. Review of Income and Wealth, 23(1), 1-16. https://doi.org/10.1111/j.14754991.1977.tb00001.x

Atkinson, A. (1981). On Intergenerational Income Mobility in Britain. Journal of Post Keynesian Economics, 3(2), 194-218.

Boltvinik, J. (1992). El método de medición integrada de la pobreza. Una propuesta para su desarrollo. Comercio Exterior, 42, 354-365.

Boltvinik, J. (2003). Conceptos y medición de la pobreza: La necesidad de ampliar la mirada. Papeles de población, 9(38), 9-25.
Boltvinik, J. (2010). Principios de Medición Multidimensional de la Pobreza. La Sociología en sus Escenarios, O(21). Recuperado de http://aprendeenlinea.udea.edu.co/revistas/index .php/ceo/article/view/7046

Callan, T., \& Nolan, B. (1991). Concepts of Poverty and the Poverty Line. Journal of Economic Surveys, 5(3), 243-261.

Desai, M., \& Shah, A. (1988). An Econometric Approach to the Measurement of Poverty. Oxford

Economic Papers, 40(3), 505-522. Recuperado de JSTOR.

Feres, J. C., \& Mancero, X. (s/f). ENFOQUES PARA LA MEDICIÓN DE LA POBREZA. BREVE REVISIÓN DE LA LITERATURA. 36.

Foster, J., Greer, J., \& Thorbecke, E. (1984). A Class of Decomposable Poverty Measures. Econometrica, 52(3), 761-766.

Hagenaars, A. J. M., \& Praag, B. M. S. van. (1985). A Synthesis of Poverty Line Definitions*. Review of Income and Wealth, 31(2), 139-154. https://doi.org/10.1111/j.14754991.1985.tb00504.x

Kakwani, N. (1980). On a Class of Poverty Measures. Econometrica, 48(2), 437. https://doi.org/10.2307/1911106

Kanbur, R., Calvo, C. M., Das Gupta, M., Grootaert, C., Kwakwa, V., \& Lustig, N. (2000). Informe sobre el desarrollo mundial 2000/2001: Lucha contra la pobreza (Núm. 22684; pp. 1338). Recuperado de The World Bank website: http://documentos.bancomundial.org/curated/es /509031468137396214/Informe-sobre-eldesarrollo-mundial-2000-2001-lucha-contra-lapobreza

Love, R., \& Oja, G. (1977). LOW INCOME IN CANADA. Review of Income and Wealth, 23(1), 39-61. https://doi.org/10.1111/j.14754991.1977.tb00003.x

Miller, S. M. (1976). The Political Economy of Social Problems: From the Sixties to the Seventies. Social Problems, 24(1), 131-141. https://doi.org/10.2307/800330 
Miller, S. M., Rein, M., Roby, P., \& Gross, B. M. (1967). Poverty, Inequality, and Conflict. The ANNALS of the American Academy of Political and Social Science, 373(1), 16-52. https://doi.org/10.1177/000271626737300102

Orshansky, M. (1965). Counting the Poor: Another Look at the Poverty Profile. 27.

Programa de las Naciones Unidas para el Desarrollo. (1997). Informe sobre desarrollo humano (Ediciones Mundi-Prensa).

Rainwater, L. (1969). The Problem of Lower Class Culture. Journal of Social Issues.

Ravallion, M. (1998). Poverty lines in theory and practice. Washington, DC: World Bank.

Ray, D. (2002). Economía del desarrollo. Antoni Bosch editor.

Rowntree, B. S. (Benjamin S. (1971). Poverty; a study of town life. Recuperado de http://archive.org/details/povertyastudyto00row ngoog

Sen, A. (1976). Poverty: An Ordinal Approach to Measurement. Econometrica, 44(2), 219. https://doi.org/10.2307/1912718

Sen, A. (1981). PUBLIC ACTION AND THE QUALITY OF LIFE IN DEVELOPING COUNTRIES*: PUBLIC ACTION AND THE QUALITY OF LIFE. Oxford Bulletin of Economics and Statistics, 43(4), 287-319. https://doi.org/10.1111/j.1468-

0084.1981.mp43004001.x

Sen, A. (1983). Poor, Relatively Speaking. Oxford Economic Papers, 35(2), 153-169.

Sen, A. (1984). Resources, Values and Development. Oxford: Basil Blackwell.

Sen, A. (2001, julio 1). Amartya Sen y las mil caras de la pobreza | IADB. Recuperado el 1 de octubre de 2019, de https://www.iadb.org/es/noticias/amartya-seny-las-mil-caras-de-la-pobreza

Sen, A. (2003). El Nivel de vida. Editorial Complutense.

Spicker, P. (1999). Definitions of poverty: Twelve clusters of meaning. 15.
Townsend, L. A. (1965). A Corporate President's View of the Internal Communication Function. Journal of Communication, 15(4), 208-215. https://doi.org/10.1111/j.14602466.1965.tb01342.x

Vogel, L. H. (1982). Poverty in the United Kingdom: A Survey of Household Resources and Standards of Living. Peter Townsend. American Journal of Sociology, 88(2), 452-454. https://doi.org/10.1086/227691

Watts, H. W. (1967). THE ISO-PROP INDEX-AN APPROACH TO THE DETERMINATION OF DIFFERENTIAL POVERTY INCOME THRESHOLDS. Recuperado de https://eric.ed.gov/?id=ED018461

World Bank. (2018). Poverty and shared prosperety. Piecing together the poverty puzzle (World Bank Group). Recuperado de https://openknowledge.worldbank.org/bitstream /handle/10986/30418/9781464813306.pdf?sequ ence $=34 \&$ is Allowed $=\mathrm{y}$ 